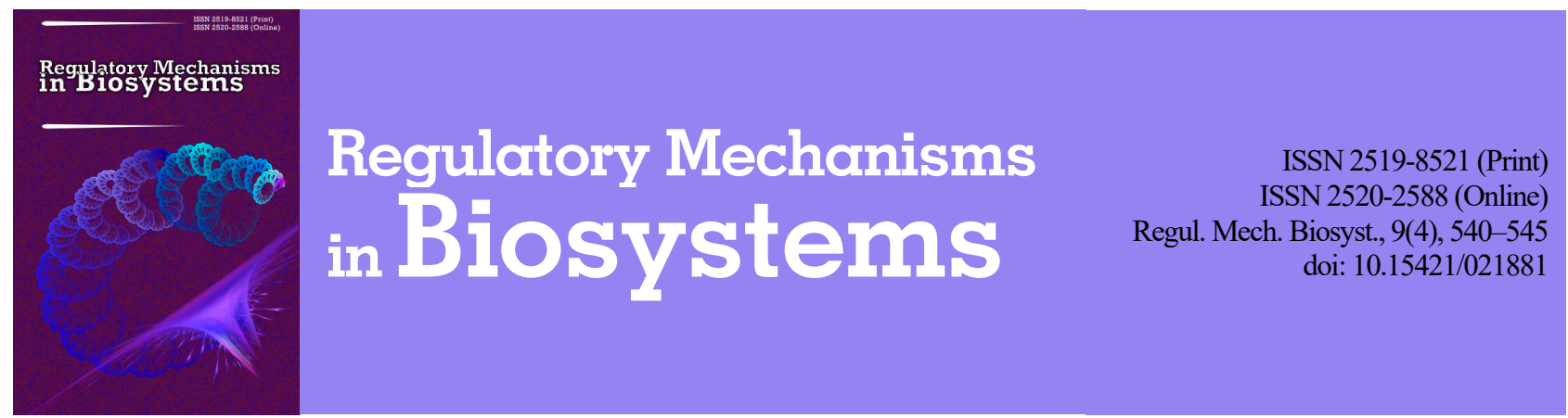

\title{
Bactericidal, protistocidal and nematodicidal properties of mixtures of alkyldimethylbenzyl ammonium chloride, didecyldimethyl ammonium chloride, glutaraldehyde and formaldehyde
}

\author{
V. V. Zazharskyi*, P. Davydenko*, O. Kulishenko*, V. Chumak*, A. Kryvaya*, \\ I. A. Biben*, N. M. Tishkina*, I. Borovik*, O. O. Boyko*, V. V. Brygadyrenko**** \\ *Dnipro State Agrarian and Economic University, Dnipro, Ukraine \\ **Oles Honchar Dnipro National University, Dnipro, Ukraine
}

Article info

Received 12.10.2018

Received in revised form 14.11.2018

Accepted 17.11.2018

Dnipro State Agrarian and Economic University Sergiy Efremov st., 25, Dnipro, 49000, Ukraine. Tel.: +38-056-713-51-74 E-mail:

boikoalexandra1982@gmail.com

Oles Honchar Dnipro National University, Gagarin av., 72, Dnipro, 49010, Ukraine. Tel.:+38-050-93-90-788. E-mail:brigad@ua.fm

\begin{abstract}
Zazharsky, V. V., Davydenko, P., Kulishenko, O., Chumak, V., Kryvaya, A., Biben, I. A., Tishkina, N. M., Borovik, I., Boyko, O. O., \& Brygadyrenko, V. V. (2018). Bactericidal, protistocidal and nematodicidal properties of mixtures of alkyldimethylbenzyl ammonium chloride, didecyldimethyl ammonium chloride, glutaraldehyde and formaldehyde. Regulatory Mechanisms in Biosystems, 9(4), 540-545. doi:10.15421/021881
\end{abstract}

We conducted a comparative analysis of the impact of disinfecting preparations on the cryogenic stains of microorganisms, and also on Haemonchus contortus (Rudolphi 1803), invasive larvae of the ruminants. To test the preparations for disinfection, we used laboratory analyses with methods of biotesting, particularly with the use of Paramecium caudatum Her., Tetrahymena pyriformis Ehrenberg. We researched mixtures of substances: alkylbenzyldimethylammonium chloride $\left(\mathrm{C}_{24} \mathrm{H}_{42} \mathrm{IN}\right.$, BAK, mixture of homologues alkylbenzyldimethylammonium chloride and with $\mathrm{n}-\mathrm{C}_{12} \mathrm{H}_{25}, \mathrm{n}-\mathrm{C}_{14} \mathrm{H}_{29}$ and $\mathrm{n}-\mathrm{C}_{16} \mathrm{H}_{33}$ ), didecyldimethylammonium Chloride (DDAC, $\left.\mathrm{C}_{22} \mathrm{H}_{48} \mathrm{CIN}\right)$ and glutaraldehyde $\left(\mathrm{C}_{5} \mathrm{H}_{8} \mathrm{O}_{2}\right)$; formaldehyde $\left(\mathrm{CH}_{2} \mathrm{O}\right)$, alkylbenzyldimethylammonium chloride and glutaraldehyde in $1 \%$ have bactericidal properties for the following cryogenic strains of microorganisms: Staphylococcus aureus, Salmonella typhimurium, Escherichia coli, Listeria monocytogenes, Proteus vulgaris, Serracia marcescens, Pseudomonas aeruginosa, Enterococcus faecalis and Yersinia enterocolitica. The Bacillus cereus were affected by the preparations bacteriostatically: we observed growth in the colonies in the medium with addition of $1 \%$ solution of mixture of alkylbenzyldimethylammonium chloride and didecyldimethylammonium chloride, and also $1 \%, 5 \%$ and $10 \%$ of solution of mixture of glutaraldehyde, formaldehyde and alkylbenzyldimethylammonium chloride. Also, these mixtures of substances have nematocidal properties. Death of $100 \%$ of $\mathrm{L}_{3} \mathrm{H}$. contortus after 24 hour exposure was observed with use of $1 \%$ solution of mixture of alkylbenzyldimethylammonium chloride and didecyldimethylammonium chloride, and also $5 \%$ - glutaraldehyde, formaldehyde and alkylbenzyldimethylammonium chloride. Effective disinfection measures perform a leading role in providing stable veterinary well-being of livestock and healthcare of the population. Maximum toxicity during usage of the mixtures on $P$. caudatum was observed for the mixture of alkylbenzyldimethylammonium chloride and didecyldimethylammonium chloride, and also for formaldehyde and glutaraldehyde. The lowest toxicity for T. pyriformis was observed with use of the mixture of glutaraldehyde, sodium dodecylsulfate (SDS) and oleum terebinthini, and also the mixture of formaldehyde and glutaraldehyde, the highest - formaldehyde and alkylbenzyldimethylammonium chloride. Thus, the most promising mixtures for use in veterinary medicine were determined to the following: alkylbenzyldimethylammonium chloride, didecyldimethylammonium chloride and glutaraldehyde, and also formaldehyde, alkylbenzyldimethylammonium chloride and glutaraldehyde.

Keywords: disinfectant; bactericidal action; toxicity; Paramecium caudatum; Tetrahymena pyriformis; Haemonchus contortus

\section{Introduction}

An obligatory component in the system of veterinary-sanitary measures for the objects of livestock farming is performance of disinfection. Prevention of diseases of infectious etiology conditioned by conditionnally-pathogenic microflora requires disruption of the epizootic chain of distribution of diseases from sources of infection. A leading role in provision of stable veterinary well-being of livestock farming and healthcare of the population is played by the conducting of effective disinfecttion measures which also cause the least possible harm to the environment. Therefore, disinfection preparations are tested using laboratory analyses with methods of biotesting, particularly with ciliates. By toxicity for the ciliates, the substances are divided into four classes: 1 (LC over $0.001 \%$ ), 2 (LC over 0.1\%), 3 (LC over 1\%), 4 (non-toxic) (Kotsumbas et al., 2006).

Correlation between the parameters of toxicity during comparative study of acute toxicity for the laboratory animals, ciliates $\sigma$ indicates that the ciliate $T$. pyriformis can be used an alternative model in predicting acute toxicity of pharmaceutical substances at the stage of their screening and pre-clinical study (Zhmin'ko et al., 2006).

The results of studies using the express-method of toxicity on ciliates indicated that solution of benzalkonium chloride, alkylbenzyldimethylammonium chloride ("Geocyd") in $0.03-0.50 \%$ concentrations and 1-10 min exposure exhibited no toxic effect on the culture of T. pyriformis ciliates (Kovalenko et al., 2014).

The extent of acute toxicity at endogastric introduction of $\mathrm{LD}_{50}$ "Univait" preparation to mice equaled $5200 \mathrm{mg} / \mathrm{kg}$ of the animal's body weight. According to the results of the studies, a preparation was developed, which belongs to the fourth class by the classification of chemical substances in relation to the extent of toxicity. "Univait" disinfecting preparation in $0.1-0.5 \%$ concentrations during $10 \mathrm{~min}$ exposure was insignificantly toxic to the cultures of T. pyriformis ciliates (Zasekin et al., 2016). For predicting toxicity of aromatic aldehydes for T. pyriformis, mathematical models are proposed, particularly the linear and nonlinear models (Ousaa et al., 2018). At the same time, there are data on the impact of aromatic aldehydes on nematode parasites of agricultural 
animals. At the impact (24h) of $1 \%$ solution of cinnamaldehyde, there was observed death of $100 \%$ of eggs of Ascaris suum $\left(\mathrm{LD}_{50}=2437 \pm\right.$ $864 \mathrm{mg} /$ l) (Boyko \& Brygadyrenko, 2017a). Larvae of Strongyloides ransomi, nematodes of pigs, also died over 24 hours at the impact of $0.1 \%$ solution of benzaldehyde. $\mathrm{LD}_{50}$ for benzaldehyde $-142 \pm 64 \mathrm{mg} / \mathrm{l}$ (Boyko \& Brygadyrenko, 2017b). The literature contains a large amount of data on the impact of alkylbenzyldimethylammonium chloride, didecyldimethylammonium chloride, formaldehyde, glutaraldehyde and other certain substances on microorganisms (Braoudaki et al., 2005; Blondeau et al., 2007; Fazlara \& Ekhtelat, 2012; Vaerewijck et al., 2012; Ivancovic et al., 2013; Lasemi, 2017). Therefore, the objective of our study was to perform a comparative assessment of bactericidal, protistocidal and nematocidal properties of mixtures of alkylbenzyldimethylammonium chloride, didecyldimethylammonium chloride and glutaraldehyde; alkylbenzyldimethylammonium chloride, formaldehyde and glutaraldehyde; sodium dodecyl sulfate (SDS), oleum terebinthini and glutaraldehyde, and also formaldehyde and glutaraldehyde.

\section{Materials and methods}

The research was conducted in the laboratories of the departments of Epizootology and Infectious Diseases of Animals, Physiology and Biochemistry of Agricultural Animals, Parasitology and VeterinarySanitary Examination of the Faculty of Veterinary Medicine of Dnipro National Agrarian-Economic University, and also in the Bacteriological Department of Dnipro Regional National Laboratory of Veterinary Medicine in 2017-2018.

Bacteria. The cultures of microorganisms of standardized strains (Table 2), cultivated on a dense growth medium over 18-24 hours were washed out with sterile isotonic solution of sodium chloride at temperature of $37 \pm 2{ }^{\circ} \mathrm{C}$. The weighed microbial amounts were processed to $5 \cdot 10^{8} \mathrm{CFU} / \mathrm{ml}$ of McFarland turbidity standard for optical standartisation of bacteria using a Dilushaker III Digital densitometer, France. The solutions of disinfectants in the working concentration $(0.9 \mathrm{ml})$ were poured into sterile test tubes. To the test tubes with disinfectant solutions $(1,5,10,25 \%), 0.1 \mathrm{ml}$ of weighed microbial amounts were added, mixed, and then the tubes were shaken for a few seconds (Table 1).

Then, $0.5 \mathrm{ml}$ of solution of the neutralizer was added (Tvin- 80 $3 \%$, saponin $-3 \%$, histidine $-0.1 \%$, cysteine $-0.1 \%$ ) and the tubes were shaken. The inoculations were made on to a specific differentialdiagnostic medium by $0.1 \mathrm{ml}$ of the mixture, and the cups with inoculated cultures were put in a thermostat for 24 hours. The methods are descrybed in detail in the articles by Zazharskyi et al. (2018a, 2018b).

The incubation was performed in accordance with the passport for the growth media. After the time necessary for the cultivation of the studied microorganisms, we assessed the number of the microorganisms that grew in the Petri dish. Distinctive typical colonies were reinoculated to beef-extract agar and incubated for 24 hours at $37^{\circ} \mathrm{C}$. The cultivated colonies underwent microscopy. If necessary, an additional identification of microorganisms was conducted in accordance with EN ISO 11133: 2014, IDT (Table 2).

Ciliates. Comparative analysis of the impact of disinfecting preparations on criogenic strains of microorganisms was performed in accordance with the generally accepted methods. The cultivation of $P$. caudatum and T. pyriformis ciliates was done in lactic media. The culture was maintained at room temperature $\left(18-20^{\circ} \mathrm{C}\right)$. For the biotesting, we used a 24-hour culture which was in the phase of exponential (active) growth. To conduct the toxicological study, we prepared a series of dissolved preparations (Table 1): $1 \%, 0.1 \%, 0.01 \%, 0.001 \%, 0.0001 \%$, $0.00001 \%$ and $0.000001 \%$.

In 5 micro-aquarium cavities $20 \mu \mathrm{l}$ of the medium with ciliates (10 20 individuals) were put. Then $20 \mu$ of aquatic solution of the studied preparations of different concentrations was added to each cavity and the number of cells in each aquarium was assessed. After 1 hour exposure, we again assessed the number of $P$. caudatum in each cavity of the aquarium and determined the percentage of their survival. During use of T. pyriformis culture, due to the small sizes of the cells and the impossibility of counting them precisely, the assessment of the biotest results was performed in relation to death of ciliates and the pattern of changes in movement. For most substances, we determined almost complete similarity in the decline angle of the straight line of lethality for ciliates and laboratory animals. This allows us to extrapolate the results of studies on protozoans to animals and humans. The values of $\mathrm{LD}_{50}$ for all studied substances, obtained using the method of expressive biotesting are within confidence intervals for $\mathrm{LD}_{50}$ values obtained experimentally (Miyoshi et al., 2003; Venkateswara et al., 2007).

Table 1

Mixtures of substances used

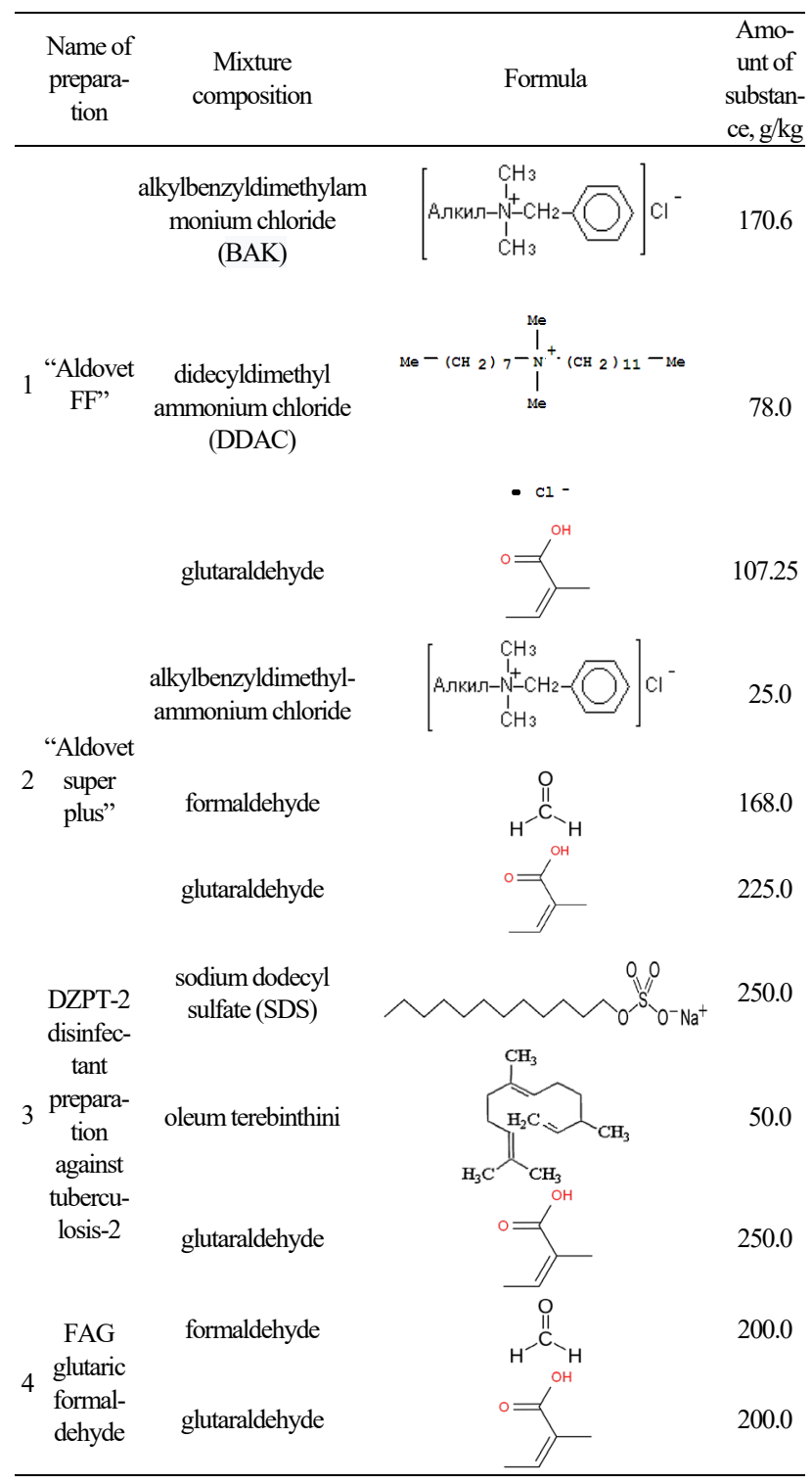

Nematoda. The larvae of nematodes in feces of ruminants were found using the Baermann test (Zajac et al., 2011). Then, $1 \mathrm{ml}$ of the studied mixtures of the substances in different concentrations $(1 \%, 5 \%$, $10 \%, 25 \%$ ) was added to each culture of $H$. contortus nematode larvae (in five times replication). The experimental exposure equaled 24 hours. We determined the number of vital and dead larvae. The methods are described in detail in articles by Boyko \& Brygadirenko (2018a, 2018b).

Statistical analysis. The extrapolation of the data on acute toxicity of the studied substances, obtained for $T$. pyriformis, to animals was implemented in accordance with the recommended methods of express biotesting. For this purpose, effective dose of a certain substance, obtained in the experiment in determining acute toxicity, was expressed as probit which was placed in the graph of the lethality line of $T$. pyriformis ciliates and $\mathrm{LC}_{50}$ value was calculated. The results are satisfactory if $\mathrm{LC}_{50}$ value obtained using the method of express biotesting is within the confidence interval (error). Value of $\mathrm{LC}_{50}$ for ciliates was determined using probit-analysis of lethality curves. Probit-analysis is recommend- 
ded by OECD Guidelines for the Testing of Chemicals for assessment of harmful impact of different toxicants. The statistical analysis of the results with $H$. contortus was performed through a set of Statistica 8.0 (StatSoft Inc., USA), the figures show the median, $25 \%$ and $75 \%$ quartiles, minimum and maximum values. $\mathrm{LD}_{50}(\%)$ was calculated as mean \pm standard deviation $(\mathrm{x} \pm \mathrm{SD})$.

\section{Results}

The mixtures we studied - alkylbenzyldimethylammonium chloride, didecyldimethyl ammonium chloride, glutaraldehyde, and also alkyl- benzyldimethylammonium chloride, formaldehyde, and glutaraldehyde demonstrated bactericidal properties even in $1 \%$ concentration against cryogenic strains of the following microorganisms: $S$. aureus, S. typhimurium, E. coli, L. monocytogenes, P. vulgaris, S. marcencens, P. aeruginosa, E. faecalis and $Y$. enterocolitica. The mixtures of these substances demonstrated a bacteriostatic effect on $B$. cereus microorganisms: growth was observed in the colonies with addition of $1 \%$ of solution of mixture of alkylbenzyldimethylammonium chloride, didecyldimethyl ammonium chloride, and glutaraldehyde, and also $1 \%, 5 \%$ and $10 \%$ solutions of mixture of alkylbenzyldimethylammonium chloride, formaldehyde, glutaraldehyde (Table 3).

\section{Table 2}

Studied growth media

\begin{tabular}{|c|c|c|c|c|}
\hline \multirow{2}{*}{$\begin{array}{c}\text { Strains of } \\
\text { microorganisms }\end{array}$} & \multicolumn{4}{|c|}{ Growth medium, HiMedia Laboratories Pvt. Limited (India) } \\
\hline & No of medium & name & base & reason for study \\
\hline $\begin{array}{l}\text { Staphylococcus } \\
\text { aureus } \\
\text { ATCC } 25923\end{array}$ & M043-500G & Baird Parker agar base & $\begin{array}{l}\text { Baird Parker agar base, } 500 \mathrm{~g} \\
\quad \text { (REF 2009/03709) } \\
\{\text { ISO 6887:2003\} }\end{array}$ & $\begin{array}{l}\text { for selection and assessment of coagulase-positive Staphylococcus in food } \\
\text { products and other examined material; FD046 egg yolk tellurite emulsion } \\
\text { (100 ml/vial) / yolk emulsion with tellurite; FD069 B P sulpha supplement } \\
\text { / additive with sulfamethazine for Baird Parker medium }\end{array}$ \\
\hline $\begin{array}{c}\text { Salmonella } \\
\text { typhimurium } 144\end{array}$ & M031-500G & $\begin{array}{l}\text { xylose lysine } \\
\text { deoxycholate agar } \\
\text { (XLD agar) }\end{array}$ & $\begin{array}{l}\text { xylose lysine deoxycholate agar } \\
\text { (XLD agar), } 500 \mathrm{~g}(\mathrm{REF} \\
\text { 2009/03709) \{ISO 6887:2003\} }\end{array}$ & for selection and assessment of Salmonella typhi and other Salmonella \\
\hline $\begin{array}{l}\text { Bacillus cereus } \\
\text { ATCC } 10702\end{array}$ & M833-500G & $\begin{array}{c}\text { Bacillus cereus agar } \\
\text { base }\end{array}$ & $\begin{array}{l}\text { Bacillus cereus agar base, } \\
500 \mathrm{~g}(\mathrm{REF} 2009 / 03709) \\
\quad\{\mathrm{ISO} 6887: 2003\}\end{array}$ & $\begin{array}{l}\text { FD003 polymyxin B selective supplement / FD045 egg yolk emulsion } \\
\text { (100 ml/vial); for selection and count of colonies of anthracoid Bacillus; } \\
\text { FD003 polymyxin B selective supplement; FD045 egg yolk emulsion } \\
(100 \mathrm{ml} / \text { vial })\end{array}$ \\
\hline $\begin{array}{l}\text { Escherichia coli } \\
\qquad(F 50)\end{array}$ & M065A & $\begin{array}{l}\text { deoxycholate citrate } \\
\text { agar (as per B.P.) }\end{array}$ & deoxycholate citrate agar & for selection of pathogens of intestinal infections \\
\hline ATCC 25922 & M1075-500G & endo agar, modified & $\begin{array}{l}\text { endo agar, modified, } 500 \mathrm{~g} \\
\text { (REF 2009/03709) }\end{array}$ & for identification and selection of coliform bacteria of the intestinal group \\
\hline $\begin{array}{l}\text { Listeria } \\
\text { monocytogenes } \\
\text { ATCC } 19112\end{array}$ & M1064-500G & $\begin{array}{l}\text { Listeria identification } \\
\text { agar base (PALCAM) }\end{array}$ & $\begin{array}{l}\text { Listeria identification agar (base) } \\
\text { (PALCAM), } 500 \mathrm{~g}(\mathrm{REF} \\
\text { 2009/03709) }\{\text { ISO 6887:2003\} }\end{array}$ & $\begin{array}{l}\text { for selection and identification of Listeria; } \\
\text { FD061 Listeria selective supplement (PALCAM) }\end{array}$ \\
\hline $\begin{array}{l}\text { Proteus vulgaris } \\
\quad H X 19222\end{array}$ & M082-500G & $\begin{array}{l}\text { MacConkey agar w/o } \\
\mathrm{CV}, \mathrm{NaCl} \text { w/sodium } \\
\text { taurocholate } 0.5 \%\end{array}$ & $\begin{array}{l}\text { MacConkey agar without crystal } \\
\text { violet, } \mathrm{NaCl} \text {, with } 0,5 \% \\
\text { taurocholic acid sodium, } \\
500 \mathrm{~g} \text { (REF 2009/03709) }\end{array}$ & $\begin{array}{l}\text { this agar is prepared in accordance with the requirements for clinical } \\
\text { microbiology; on this differential medium, swarming of most strains of } \\
\text { Proteus is inhibited, which significantly facilitates the selection of } \\
\text { intestinal bacteria; along with opportunistic gram-positive bacteria, a large } \\
\text { number of Proteus can be maintained in it; enterococci in it form small } \\
\text { reddish colonies }\end{array}$ \\
\hline $\begin{array}{c}\text { Seratia } \\
\text { marcescens } 1\end{array}$ & M001-500G & nutrient agar & $\begin{array}{l}\text { nutrient agar, } 500 \mathrm{~g} \\
\text { (REF 2009/03709) } \\
\{\text { ISO 6579:2002\} }\end{array}$ & $\begin{array}{l}\text { is used as the main medium for cultivating not very fastidious } \\
\text { microorganisms or for preparing special media (after } 10 \% \text { of blood } \\
\text { or other biological fluid) }\end{array}$ \\
\hline $\begin{array}{l}\text { Pseudomonas } \\
\text { aeruginosa } \\
\text { ATCC } 2853(F)\end{array}$ & M085-500G & Pseudomonas agar base & $\begin{array}{l}\text { basis for the agar for } \\
\text { Pseudomonas, } 500 \mathrm{~g} \\
\text { (REF 2009/03709) }\end{array}$ & $\begin{array}{l}\text { is recommended with additives for selection of Pseudomonas; } \\
\text { recommended by the International Committee (ISO); FD029 cetrinix } \\
\text { supplement / cetrinix additive for Pseudomonas }\end{array}$ \\
\hline $\begin{array}{l}\text { Enterococcus } \\
\quad \text { faecalis }\end{array}$ & M001-500G & nutrient agar & $\begin{array}{l}\text { nutrient agar, } 500 \mathrm{~g} \\
\text { (REF 2009/03709) } \\
\text { \{ISO 6579:2002\} }\end{array}$ & $\begin{array}{l}\text { is used as the main medium for cultivating not very fastidious } \\
\text { microorganisms or for preparing special media (after } 10 \% \text { of blood or } \\
\text { other biological fluid) }\end{array}$ \\
\hline ATCC 19433 & M1075-500G & endo agar, modified & $\begin{array}{l}\text { endo agar, modified, } \\
500 \mathrm{~g}(\text { REF } 2009 / 03709)\end{array}$ & $\begin{array}{l}\text { for determining and selecting coliform and other bacteria } \\
\text { of the intestinal group }\end{array}$ \\
\hline $\begin{array}{c}\text { Yersinia } \\
\text { enterocolitica }\end{array}$ & M1075-500G & endo agar, modified & $\begin{array}{l}\text { nutrient agar, } 500 \mathrm{~g} \\
\quad \text { (REF 2009/03709) } \\
\text { \{ISO 6579:2002\} } \\
\text { endo agar, modified, } 500 \mathrm{~g} \\
\quad \text { (REF 2009/03709) }\end{array}$ & $\begin{array}{l}\text { is used as the main medium for cultivating not very fastidious } \\
\text { microorganisms or for preparing special media } \\
\text { (after adding } 10 \% \text { of blood or other biological fluid) } \\
\text { for identification and selection of the coliform and other bacteria } \\
\text { of the intestinal group }\end{array}$ \\
\hline
\end{tabular}

No negative impact on the mobility of $T$. pyriformis was demonstrated by the mixtures of sodium dodecyl sulfate (SDS), essential oil, glutaraldehyde, and also formaldehyde, glutaraldehyde with $0.01 \%$, mixtures of alkylbenzyldimethylammonium chloride, didecyldimethyl ammonium chloride, glutaraldehyde and also alkylbenzyldimethylammonium chloride, formaldehyde, glutaraldehyde with $0.0001 \%$ (Table 4). According to the results of our previous studies (Zazharskyi et al., 2018a, 2018b), the impact of $0.01 \mathrm{mg} / \mathrm{l}$ of mixture of alkylbenzyldimethylammonium chloride, didecyldimethyl ammonium chloride, glutaraldehyde and formaldehyde, and glutaraldehyde caused the highest death rate of ciliates $-26 \%$ and $22 \%$ respectively (Table 5). $\mathrm{LC}_{50}$ equaled $1.8 \mathrm{mg} / \mathrm{l}$ with use of the mixture of alkylbenzyldimethylammonium chloride, didecyldimethyl ammonium chloride, glutaraldehyde, $8.4 \mathrm{mg} / \mathrm{l}$ - formaldehyde, glutaraldehyde, $27.2 \mathrm{mg} / \mathrm{l}$ - alkylbenzyldimethylammonium chloride, formaldehyde, glutaraldehyde, $53.4 \mathrm{mg} / \mathrm{l}-$ sodium dodecyl sulfate, essential oil, and glutaraldehyde. In the series of experiments on ciliates, the death of different numbers of them was ob- served in interval $0.001-10 \mathrm{mg} / \mathrm{l}$ with use of the mixture of alkylbenzyldimethylammonium chloride, didecyldimethyl ammonium chloride, glutaraldehyde and formaldehyde, glutaraldehyde, $0.001-100 \mathrm{mg} / \mathrm{l}-$ alkylbenzyldimethylammonium chloride, formaldehyde, glutaraldehyde, $0.1-100 \mathrm{mg} / \mathrm{l}$ for sodium dodecyl sulfate, essential oil, glutaraldehyde.

The greatest impact on the vitality of nematode larvae in the environment was demonstrated by alkylbenzyldimethylammonium chloride, didecyldimethyl ammonium chloride and glutaraldehyde. 100\% death rate of $H$. contortus, nematode larvae of ruminants was observed with use of $1 \%$ solution of this mixture. Nematocidal effect was exhibited by the mixture of alkylbenzyldimethylammonium chloride, formaldehyde and glutaraldehyde: nematode larvae of the studied species died at $5 \%$ concentration. Mixtures of sodium dodecyl sulfate, oleum terebinthini, glutaraldehyde, and also formaldehyde and glutaraldehyde were the least efficient against invasive larvae of $H$. contortus. $100 \%$ death rate of $\mathrm{L}_{3}$ larvae was observed only when $25 \%$ solution of mixtures of these substances was used (Fig. 2). 
Table 3

Influence of the studied mixtures on cryogenic strains of microorganisms $(\mathrm{n}=5)$

\begin{tabular}{|c|c|c|c|c|c|c|c|c|c|c|c|c|c|c|c|c|}
\hline \multirow[t]{2}{*}{ Strains of microorganisms } & \multicolumn{4}{|c|}{$\begin{array}{l}\text { Alkylbenzyldimethylammonium } \\
\text { chloride, didecyldimethyl ammonium } \\
\text { chloride, glutaraldehyde, } \%\end{array}$} & \multicolumn{4}{|c|}{$\begin{array}{c}\text { Alkylbenzyldimethyl-ammonium } \\
\text { chloride, formaldehyde, } \\
\text { glutaraldehyde, } \%\end{array}$} & \multicolumn{4}{|c|}{$\begin{array}{l}\text { Sodium dodecyl sulfate, } \\
\text { essential oil, glutaraldehyde, \% }\end{array}$} & \multicolumn{4}{|c|}{$\begin{array}{l}\text { Formaldehyde, } \\
\text { glutaraldehyde, } \%\end{array}$} \\
\hline & 1 & 5 & 10 & 25 & 1 & 5 & 10 & 25 & 1 & 5 & 10 & 25 & 1 & 5 & 10 & 25 \\
\hline S. aureus ATCC 25923 & - & - & - & - & - & - & - & - & + & - & - & - & - & - & - & - \\
\hline S. typhimurium 144 & - & - & - & - & - & - & - & - & + & + & - & - & - & - & - & - \\
\hline B. cereus ATCC 10702 & + & - & - & - & + & + & + & - & $+1+$ & $+1+$ & + & ++ & $+\mathrm{H}$ & $+1+$ & + & + \\
\hline E. coli (F 50) ATCC 25922 & - & - & - & - & - & - & - & - & + & - & - & - & - & - & - & - \\
\hline $\begin{array}{l}\text { L. monocytogenes ATCC } \\
19112\end{array}$ & - & - & - & - & - & - & - & - & + & - & - & - & + & - & - & - \\
\hline P. vulgaris $H X 19222$ & - & - & - & - & - & - & - & - & + & - & - & - & - & - & - & - \\
\hline S.marcescens 1 & - & - & - & - & - & - & - & - & - & - & - & - & - & - & - & - \\
\hline P. aeruginosa ATCC 2853(F) & - & - & - & - & - & - & - & - & + & + & - & - & + & $H$ & + & - \\
\hline E. faecalis ATCC 19433 & - & - & - & - & - & - & - & - & + & + & - & - & + & + & + & - \\
\hline Y. enterocolitica & - & - & - & - & - & - & - & - & + & - & - & - & - & - & - & - \\
\hline
\end{tabular}

Note: "-"- no growth in colonies, "+" - one colony, "++" - two colonies, "+++"- three colonies.

Table 4

Influence of studied substances on T. pyriformis $(\mathrm{n}=5)$

\begin{tabular}{|c|c|c|c|c|c|}
\hline \multirow[b]{2}{*}{$\begin{array}{c}\text { Concentration, } \\
\%\end{array}$} & \multirow[b]{2}{*}{$\begin{array}{l}\text { Exposure, } \\
\text { hour }\end{array}$} & \multicolumn{4}{|c|}{ Types of mixtures } \\
\hline & & $\begin{array}{c}\text { alkylbenzyldimethylammonium chloride, } \\
\text { didecyldimethyl ammonium chloride, glutaraldehyde }\end{array}$ & $\begin{array}{l}\text { alkylbenzyldimethylammonium chloride, } \\
\text { formaldehyde, glutaraldehyde }\end{array}$ & $\begin{array}{l}\text { sodium dodecyl sulfate, } \\
\text { essential oil, glutaraldehyde }\end{array}$ & $\begin{array}{l}\text { formaldehyde, } \\
\text { glutaraldehyde }\end{array}$ \\
\hline \multirow{2}{*}{0.1} & 1 & - & - & - & - \\
\hline & 24 & - & - & - & - \\
\hline \multirow{2}{*}{$1.0 \times 10^{-2}$} & 1 & $\pm^{1}$ & -1 & $\pm^{4}$ & $\pm^{4}$ \\
\hline & 24 & $\pm^{2}$ & - & + & + \\
\hline \multirow{2}{*}{$1.0 \times 10^{-3}$} & 1 & $\pm^{5}$ & $\pm^{6}$ & + & + \\
\hline & 24 & + & - & + & + \\
\hline \multirow{2}{*}{$1.0 \times 10^{-4}$} & 1 & + & $\pm^{7}$ & + & + \\
\hline & 24 & + & + & + & + \\
\hline \multirow{2}{*}{$1.0 \times 10^{-5}$} & 1 & + & + & + & + \\
\hline & 24 & + & + & + & + \\
\hline \multirow{2}{*}{$1.0 \times 10^{-6}$} & 1 & + & + & + & + \\
\hline & 24 & + & + & + & + \\
\hline
\end{tabular}

Note: "_ - no growth (death), " \pm " - movement slowed, "+" - active movement; 1 - after the addition, movement intensifies, the direction changes, after $60 \mathrm{~min}$ - single moving individuals, movement slowed; 2 - restoration of movement, decrease in density of the culture, movement slowed; 3 - restoration of movement, decrease in density of the culture, movement slowed; 4 - insignificant decrease in density; 5 - slowed movement; 6 - rotation, slowed movement, decrease in density; 7 - slowed movement, insignificant decrease in density (Zhmin'ko et al., 2006).

Table 5

Influence of the studied substances on P. caudatum ( $\%$ dead ciliates; $\mathrm{n}=5$ )

\begin{tabular}{|c|c|c|c|c|c|c|c|c|c|c|}
\hline \multirow{3}{*}{ Mixture compound } & \multicolumn{10}{|c|}{ Concentration of mixtures in the sample, $\mathrm{mg} / \mathrm{l}$} \\
\hline & \multicolumn{2}{|c|}{0.01} & \multicolumn{2}{|r|}{0.1} & \multicolumn{2}{|c|}{1} & \multicolumn{2}{|c|}{10} & \multicolumn{2}{|c|}{100} \\
\hline & control & experiment & control & experiment & control & experiment & control & experiment & control & experiment \\
\hline $\begin{array}{l}\text { Alkylbenzyldimethylammonium chloride, didecyldimethyl } \\
\text { ammonium chloride, glutaraldehyde }\end{array}$ & 0 & 26 & 0 & 42 & 0 & 66 & 0 & 100 & 0 & 100 \\
\hline $\begin{array}{l}\text { Alkylbenzyldimethylammonium chloride, formaldehyde, } \\
\text { glutaraldehyde }\end{array}$ & 0 & 12 & 0 & 23 & 0 & 33 & 0 & 65 & 0 & 100 \\
\hline Sodium dodecyl sulfate, oleum terebinthini, glutaraldehyde & 0 & 0 & 0 & 12 & 0 & 12 & 0 & 7 & 0 & 100 \\
\hline Formaldehyde, glutaraldehyde & 0 & 22 & 0 & 21 & 0 & 40 & 0 & 100 & 0 & 100 \\
\hline
\end{tabular}

During usage of mixture of sodium dodecyl sulfate, oleum terebinthini and glutaraldehyde in 5\% concentration, the vitality of nematode larvae was observed on average to be $25 \%$, in $10 \%$ concentration it was $8 \%$ of individuals. When the mixture of formaldehyde, glutaraldehyde was used in $1 \%, 5 \%$ and $10 \%$ concentration, on average $1-10 \%$ of individuals survived. $\mathrm{LD}_{50}$ for mixture of sodium dodecyl sulfate, essential oil and glutaraldehyde equals $2.3 \pm 0.8 \%$, for formaldehyde, glutaraldehyde it was $0.45 \pm 0.16 \%$.

\section{Discussion}

The series of studies Takashi \& Kei-Ichiro (2007) proved the bactericidal effect of didecyldimethyl ammonium chloride in minimum inhibiting concentration $1.3 \mathrm{mg} / \mathrm{l}$ against $E$. coli. The studies by Shirron et al. (2009) allow us to state that didecyldimethyl ammonium chloride causes a bactericidal effect against $S$. typhimurium. Walsh et al. (2003) reported that didecyldimethyl ammonium chloride has a bactericidal effect on $E$. coli, $S$. aureus, P. aeruginosa and L. monocytogenes. According to Ioannou et al. (2007), alkylbenzyldimethylammonium chloride and dide- cyldimethyl ammonium chloride are at the same time membrane-active agents with subtly different mechanisms of action, which reflect the previous interaction with $S$. aureus.

The studies by Lasemi et al. (2017) demonstrated the impact of $2 \%$ solution of glutaraldehyde on the spores of $B$. subtilis. The results showed that 102 colonies were present on the 10th minute, $18.6 \pm 3.4$ on the 15 th minute, $6.2 \pm 1.4$ on the 20 th minute, $2.1 \pm 0.8$ on the 25 th minute and no colonies after 30 minutes. Over the first 10 minutes, more colonies were observed, after 15-20 minutes this number significantly reduced. After 30 minutes, growth of the colonies completely stopped. $2 \%$ density of glutaraldehyde over 30 minutes was sufficient for eliminating the spores of $B$. subtilis. The data by Simões et al. (2008) indicate that sodium dodecyl sulfate has an antimicrobal effect on the biomembranes of $P$. fluorescens. In their studies, Chen et al. (2016) mention that pathogenic strains of $E$. coli, $P$. aeruginosa and $K$. pneumoniae have a FrmRAB regulator, and can be used for eliminating endogenous and exogenous Formaldehyde.

Vaerewijck et al. (2012) determined that alkylbenzyldimethylammonium chloride and sodium hypochlorite in concentration of active 
chlorine of $50 \mathrm{mg} / \mathrm{l}$ can inactivate Acanthamoeba and two species of Tetrahymena spp. in 15 minutes. The series of studies by Ivancovic et al. (2013) proved the lethal effect of alkylbenzyldimethylammonium chloride on Paramecium caudatum. The studies by Blondeau et al. (2007) allow us to state that alkylbenzyldimethylammonium chloride in a combination with gatifloxacin and moxifloxacinin in concentration of 0.008 $0.125 \mathrm{mg} / \mathrm{l}$ exhibited bactericidal effect against polyresistent $S$. aureus. The studies by Braoudaki et al. (2005) demonstrated that alkylbenzyldimethylammonium chloride in combination with erythromycin has a bactericidal effect against S. typhimurium. Fazlara \& Ekhtelat (2012) described the lethal influence of alkylbenzyldimethylammonium chloride on $B$. cereus. In their studies, Carmen Velázquez et al. (2009) also mentioned that alkylbenzyldimethylammonium chloride has a bactericidal effect against E. coli. The studies by Bridier et al. (2011) allow us to state that alkylbenzyldimethylammonium chloride has a bactericidal effect on $E$. faecalis.

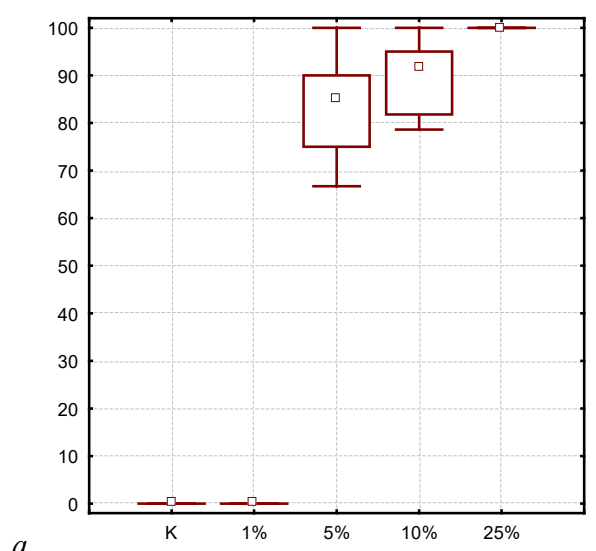

$a$

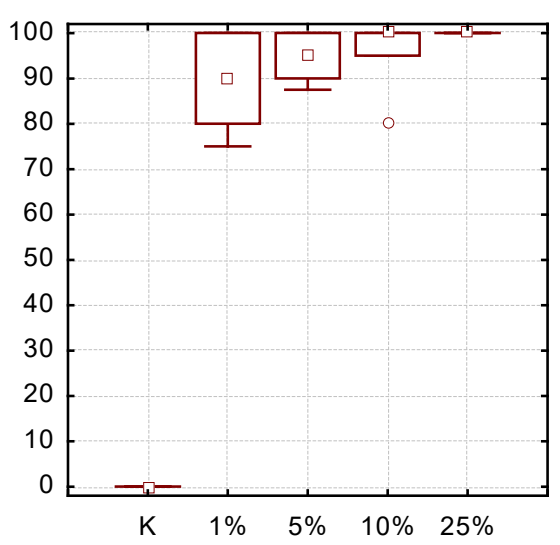

$b$

Fig. 2. Influence of the studied mixtures on vitality of nematode

larvae of H. contortus: $a$ - sodium dodecyl sulfate, oleum terebinthini, glutaraldehyde, $b$ - formaldehyde, glutaraldehyde

Ibusquiza P. Saá et al. (2011) found resistance of Listeria monocytogenes to alkylbenzyldimethylammonium chloride. Hattori et al. (2003) observed resistance to this substance by $P$. vulgaris. Tiwari et al. (2003) also proved the resistance of Serratia marcescens to this substance. By contrast, Paul et al. (2010) allow us to state that alkylbenzyldimethylammonium chloride shows no bactericidial effect against $P$. aeruginosa.

There are data on using mixtures of formaldehyde and glutaraldehyde as a disinvasive preparation. The study by Palij et al. (2018) describes the effect of FAG aldehyde preparation on the eggs of nematodes of agricultural animals. It was determined that the preparation in $6.0 \%$ concentration at 24 hours exposition demonstrates a disinvasive effect against eggs of Ascaris suum, Ascaridia galli and Toxocara canis. Mixture of these aldehydes is an efficient preparation for disinfecting the premises of livestock contaminated with invasive helminths.

The highest bactericidal, protistocidal, and also nematodicidal effect were observed for use of mixtures of alkylbenzyldimethylammonium chloride, didecyldimethyl ammonium chloride and glutaraldehyde, and also alkyldimethylbenzylammonium chloride, formaldehyde and glutaraldehyde.
Mixtures of alkylbenzyldimethylammonium chloride, formaldehyde, glutaraldehyde, and also alkylbenzyldimethylammonium chloride, didecyldimethyl ammonium chloride, and glutaraldehyde demonstrated bactericidal properties on cryogenic strains of $S$. aureus, S. typhimurium, E. coli, L. monocytogenes, $P$. vulgaris, $S$. marcescens, $P$. aeruginosa, $E$. faecalis, and $Y$. enterocolitica, and also nematocidal properties against $H$. contortus, nematode larvae of ruminants. Maximum toxicity during use of the studied substances against $P$. caudatum was demonstrated by alkylbenzyldimethylammonium chloride, didecyldimethyl ammonium chloride, glutaraldehyde, and also formaldehyde and glutaraldehyde. The least toxic were mixtures of sodium dodecyl sulfate, oleum terebinthini, and glutaraldehyde (14-15 times safer). The mixture alkylbenzyldimethylammonium chloride, formaldehyde and glutaraldehyde showed a moderate level of toxicity. The least toxicity for $T$. pyriformis was observed for the mixture of sodium dodecyl sulfate, essential oil, glutaraldehyde, and also formaldehyde and glutaraldehyde, the highest for alkylbenzyldimethylammonium chloride, formaldehyde, and glutaraldehyde. The strongest effect on the viability of nematode larvae in the environment was shown by alkylbenzyldimethylammonium chloride, didecyldimethyl ammonium chloride, and glutaraldehyde. 100\% death rate of $H$. contortus, nematode larvae of ruminants, was recorded already at using $1 \%$ solution of this mixture. Nematocidal effect was observed for mixture of alkylbenzyldimethylammonium chloride, formaldehyde, and glutaraldehyde: nematode larvae of the studied species died at $5 \%$ concentration. Thus, our observations can be useful for practicing doctors of human and veterinary medicine during preparation of antiseptics, disinfecting and disinvasive preparations with predicted biocidal effect of four ammonium compounds.

\section{References}

Blondeau, J. M., Borsos, S., \& Hesje, C. K. (2007). Antimicrobial efficacy of gatifloxacin and moxifloxacin with and without benzalkonium chloride compared with ciprofloxacin and levofloxacin against methicillin-resistant Staphylococcus aureus. Journal of Chemotherapy, 19(2), 146-151.

Boyko, A. A., \& Brygadyrenko, V. V. (2017a). Changes in the viability of the eggs of Ascaris suum under the influence of flavourings and source materials approved for use in and on foods. Biosystems Diversity, 25(2), 162-166.

Boyko, A. A., \& Brygadyrenko, V. V. (2017b). Changes in the viability of Strongyloides ransomi larvae (Nematoda, Rhabditida) under the influence of synthetic flavourings. Regulatory Mechanisms in Biosystems, 8(1), 36-40.

Boyko, O. O., \& Brygadyrenko, V. V. (2018a). The impact of certain flavourings and preser-vatives on the survivability of larvae of nematodes of Ruminantia. Regulatory Mechanisms in Biosystems, 9(1), 118-123.

Boyko, O. O., Gavrilina, O. G., Gavrilin, P. N., Gugosyan, Y. A., \& Brygadyrenko, V. V. (2018b). Influence of formic acid on the vitality of Strongyloides papillosus. Regulatory Mechanisms inBiosystems, 9(3), 435-439.

Braoudaki, M., \& Hilton, A. C. (2005). Mechanisms of resistance in Salmonella enterica adapted to erythromycin, benzalkonium chloride and triclosan. International Journal of Antimicrobial Agents, 25(1), 31-37.

Bridier, A., Briandet, R., Thomas, V., \& Dubois-Brissonnet, F. (2011). Comparative biocidal activity of peracetic acid, benzalkonium chloride and orthophthalaldehyde on 77 bacterial strains. Journal of Hospital Infection, 78(3), 208-213.

Chen, N. H., Djoko, K. Y., Veyrier, F. J., \& McEwan, A. G. (2016). Formaldehyde stress responses in bacterial pathogens. Frontiers in Microbiology, 7, 257.

del Carmen Velazquez, L., Barbini, B. N., Escudero, M. E., \& Estrada, C. L., de Guzman, A. M. S. (2009). Evaluation of chlorine, benzalkonium chloride and lactic acid as sanitizers for reducing Escherichia coli O157:H7 and Yersinia enterocolitica on fresh vegetables. Food Control, 20(3), 262-268.

Fazlara, A., \& Ekhtelat, M. (2012). The disinfectant effects of benzalkonium chloride on some important foodborne pathogens. American-Eurasian Journal of Agricultural and Environmental Sciences, 12(1), 23-29.

Hattori, N., Sakakibara, T., Kajiyama, N., Igarashi, T., Maeda, M., \& Murakami, S. (2003). Enhanced microbial biomass assay using mutant luciferase resistant to benzalkonium chloride. Analytical Biochemistry, 319(2), 287-295.

Ibusquiza, P. S., Herrera, J. J. R., \& Cabo, M. L. (2011). Resistance to benzalkonium chloride, peracetic acid and nisin during formation of mature biofilms by Listeria monocytogenes. Food Microbiology, 28(3), 418- 425.

Ioannou, C. J., Hanlon, G. W., \& Denyer, S. P. (2007). Action of disinfectant quaternary ammonium compounds against Staphylococcus aureus. Antimicrobial Agents and Chemotherapy, 51(1), 296-306.

Ivancovic, T., Hrenovic, J., \& Matonickin-Kepcija, R. (2013). Resistance of bioparticles formed of phosphate-accumulating bacteria and zeolite to harsh 
environmental conditions. The Journal of Bioadhesion and Biofilm Research, 29(6), 641-649.

Kotsumbas, I. Y., Malyk, O. G., \& Paterega, I. P. (2006). Doklinichni doslidzhennya veterinarnih likarskih zasobiv [Preclinical studies of veterinary medicinal products]. Triada Plus, Lviv (in Ukrainian).

Kovalenko, V. L., Gnatenko, A. V., \& Ponomarenko, G. V. (2012). Porivnialne vyznatchennya toksichnosti bacteritsydnyh zasobiv za pokaznykamy gostroyi toksychnosti ta alternatyvnyh metodiv [Comparative definition of toxicity of bactericidal agents on indicators of acute toxicity and alternative methods]. Problems of Zoinengineering and Veterinary Medicine, 25(2), 169-173 (in Ukrainian).

Kovalenko, V. L., Lyasota, V. P., \& Balats'kij, Y. O. (2014). Viznachennya toksichnosti dezinfikuyuchogo preparatu "Geotsid" z vikoristannyam infuzoriji Tetrachynema pyriformis [Determination of the toxicity of the disinfectant "Geocid" using the Tetrachynema pyriformis infusoria]. Problems of Zoinengineering and Veterinary Medicine, 29(2), 262-265 (in Ukrainian).

Lasemi, E., Kalantar, M. H., Navi, M. F., Rezae, M., Nikfar, N. H., Danial, Z., \& Azizpour, R. (2017). Effects of different times of glutaraldehyde $2 \%$ on $B a$ cillus subtilis spores (in vitro). Hospital Practices and Research, 2(4), 118-121.

Mc Cay, P. H., Ocampo-Sosa, A. A., \& Fleming, G. T. (2010). Effect of subinhibitory concentrations of benzalkonium chloride on the competitiveness of Pseudomonas aeruginosa grown in continuous culture. Microbiology, 156(1), 30-38.

Miyoshi, N., Kawano, T., \& Tanaka, M. (2003). Use of Paramecium species in bioassays for environmental risk management: Determination of $\mathrm{LC}_{50}$ values for water pollutants. Journal of Health Science, 49(6), 429-435.

Ousaa, A., Elidrissi, B., Ghamali, M., Chtita, S., Aouidate, A., Bouachrine, M., \& Lakhlifi, T. (2018). Quantitative structure-toxicity relationship studies of aromatic aldehydes to Tetrahymena pyriformis based on electronic and topological descriptors. Journal of Materials and Environmental Science, 9(1), 256-266.

Palij, A. P., \& Sumakova, N. V. (2018). Viznachennya dezinvazijnikh vlastivostej dezzasobu "FAG" [Determination of disinfesive properties of disinfection "FAG"]. Veterinary Biotechnology, 32(2), 405-412.

Shirron, N., Kisluk, G., Zelikovich, Y., Eivin, I., Shimoni, E., \& Yaron, S. (2009). A comparative study assaying commonly used sanitizers for antimicrobial activity against indicator bacteria and a Salmonella typhimurium strain on fresh produce. Journal of Food Protection, 72(11), 2413-2417.

Simões, M., Simões, L. C., Pereira, M. O., \& Vieira, M. J. (2008). Sodium dodecyl sulfate allows the persistence and recovery of biofilms of Pseudomonas fluorescens formed under different hydrodynamic conditions. Biofouling, 24(1), 35-44.
Tiwari, T. S., Ray, P. B., Jost, K. C., Rathod, M. K., Zhang, Y., Brown-Elliott, B. A., Hendricks, K., \& Wallace, R. J. (2003). Forty years of disinfectant failure: Outbreak of postinjection Mycobacterium abscessus infection caused by contamination of benzalkonium chloride. Clinical Infectious Diseases, 36(8), 954-962.

Vaerewijck, M., Sabbe, K., Bare, J., Spengler, H.-P., Favoreel, H., \& Houf, K. (2012). Assessment of the efficacy of benzalkonium chloride and sodium hypochlorite against Acanthamoeba polyphaga and Tetrahymena spp. Journal of Food Protection, 75(3), 541-546.

Venkateswara Rao, J., Gunda, V., Srikanth, K., \& Arepalli, S. K. (2007). Acute toxicity bioassay using Paramecium caudatum, a key member to study the effects of monocrotophos on swimming behaviour, morphology and reproduction. Toxicological and Environmental Chemistry, 89(2), 307-317.

Walsh, S. E., Maillard, J.-Y., Catrenich, C. E., Charbonneau, D. L., \& Bartolo, R. G. (2003). Activity and mechanisms of action of selected biocidal agents on Gram-positive and negative bacteria. Journal of Applied Microbiology, 94(2), 240-247.

Yoshimatsu, T., \& Hiyama, K. (2007). Mechanism of the action of didecyldimethylammonium chloride (DDAC) against Escherichia coli and morphological changes of the cells. Biocontrol Science, 12(3), 93-99.

Zasckin, D. A., Dimko, R. O., \& Kovalenko, V. L. (2016). Efektivnist' dezinfektantu na osnovi organichnikh kislot ta nanochastinok metaliv shhodo testkul'tur mikroorganizmiv [Efficiency of disinfectant based on organic acids and nanoparticles of metals in relation to test cultures of microorganisms]. Problems of Zoinengineering and Veterinary Medicine, 30(2), 358-360 (in Ukrainian).

Zazharskyi, V. V., Davydenko, P., Kulishenko, O., Chumak, V., Kryvaya, A., Babaruk, A., \& Borovik, I. (2018b). Porivnyal'na otsinka bakteritsidnikh vlastivostej dezinfektantiv [Comparative assessment of bactericidal properties of disinfectants]. Bulletin of the Sumy National Agrarian University, 42(1), 273-276 (in Ukrainian).

Zazharskyi, V. V., Fotina, T. I., Berezovsky, A. V., Davydenko, P., Kulishenko, O., Chumak, V., Kryvaya, A., \& Borovik, I. (2018a). Vpliv dezinfikuyuchikh zasobiv na kriogenni shtami mikroorganizmiv [Influence of disinfectants on cryogenic strains of microorganisms]. The Journal of the Dnipropetrovsk State Agrarian and Economic University, Veterinary Sciences, 47(1-2), 53-58 (in Ukrainian).

Zhmin'ko, P. G., Kokshariova, N. V., \& Dmytrenko, M. P. (2006). Dosvid v skriningovyh doslidzhenniyah toksitchnosti likarskih zasobiv [Experience of using different test systems in screening studies on drug toxicity]. Bulletin of Pharmacology and Pharmacy, 4, 21-27 (in Ukrainian). 